\title{
Resynchronisation as an element of improving cattle reproduction efficiency
}

\author{
Jędrzej M. Jaśkowski, Marek Gehrke, Magdalena Herudzińska, \\ Bartłomiej M. Jaśkowski ${ }^{1}$, Klaus-Peter Brüssow \\ Veterinary Centre of Nicolaus Copernicus University, 87-100 Toruń, Poland \\ ${ }^{1}$ Department of Reproduction and Clinic of Farm Animals, Faculty of Veterinary Medicine, \\ Wrocław University of Environmental and Life Sciences, 50-366 Wrocław, Poland \\ mherudzinska@umk.pl
}

Received: July 16, $2018 \quad$ Accepted: February 12, 2019

\begin{abstract}
Oestrus resynchronisation (RES, Resynch) programmes for non-pregnant cows allow shortening the period between an unsuccessful insemination and the next attempt on the same cow. The protocol of oestrus RES may be started after ruling out pregnancy by means of ultrasonography carried out 28 days after insemination or after performing a test for pregnancy-specific glycoproteins (PAG) in blood or milk. The Resynch protocol can be based on a double application of prostaglandins, the OvSynch protocol, or hormonal therapy with exogenous sources of progesterone (CIDR intravaginal devices). The efficiency of the method depends on the functional state of the ovaries, the diameter of the corpus luteum, external factors, and the health and maturity of the cows. The present paper constitutes a comparison of research findings concerning the effectiveness of RES programmes.
\end{abstract}

Keywords: cattle, resynchronisation, reproduction, pregnancy.

\section{Introduction}

Programmes of oestrus resynchronisation (RES) for non-pregnant cows are a way to shorten the period between an unsuccessful insemination and the following attempt on the same animal. Besides earliest possible insemination after parturition and maintenance of a high first conception rate (FCR), re-insemination of non-pregnant cows is one of the crucial aspects that determine success in cattle reproduction. It can be performed to the following scheme: 1) ruling out pregnancy; 2) starting hormonal therapy, i.e. induction of oestrus or possibly of oestrus and ovulation (OvSynch) along with timed artificial insemination (TAI); 3) introducing a cascade of hormonal programmes used in reproduction management; or 4) simultaneous introduction of the aforementioned hormonal programmes, along with the earliest possible pregnancy diagnosis.

Resynchronisation protocols describe the rules of hormonal intervention in the di- and pro-oestrus periods, which occur after an unsuccessful TAI procedure, or after ruling out pregnancy using an ultrasonography (US) scan on day 28 after insemination. Diagnosis of pregnancy by ultrasonography, which is made earlier than diagnosis made by rectal palpation, is a very useful tool that influences the reproductive capacity and efficiency of cows, especially in the context of occurrences of embryo mortality. Although cows which show heat symptoms without previous exogenous hormonal stimulation achieve a higher pregnancy rate than cows subjected to an oestrus synchronisation protocol, the period between parturition and the next pregnancy (open days) is in their case significantly higher than in the case of cows which have been subjected to TAI. Almost all RES programmes are based on prostaglandin F (PGF) and GnRH analogue (GnRH) injections at an appropriate time and dose (29).

Early ruling out of pregnancy. Some nonpregnant cows show clear oestrus symptoms early and are re-inseminated within 20-25 days; the remaining non-pregnant females can be detected only until the pregnancy diagnosis is performed. Bearing in mind that 
the pregnancy examinations are mostly conducted at about 30, and sometimes even 45-60 days after insemination, the period between an unsuccessful insemination and another oestrus cycle and insemination may be as long as four to eight weeks (10). For that reason, with a low calving rate (CR) late diagnosis may generally affect the reproductive result of a whole herd. The classic pregnancy detection methods include clinical per rectum examination, which is characterised by low invasiveness and high accuracy (41). At present, a standard procedure conducted in field conditions is pregnancy detection by means of US scan (10). This procedure allows diagnosing pregnancy between 25 and 30 days after insemination. However, early examination (25-27 days after insemination) is characterised by lower specificity, meaning that the females which are not found to be pregnant may actually be. The consequence of that may be an erroneous diagnosis, which, in the case of applying prostaglandin to a cow considered nongravid, may lead to economic losses resulting from a failed pregnancy and undesirable prolongation of the inter-pregnancy period (36). A US scan requires a portable ultrasound scanner of satisfactory quality, as well as experience gained in the course of examinations (25).

Production of progesterone and the texture of the corpus luteum (CL) evaluated on US images change at the end of the oestrus cycle. Non-pregnant animals can be detected with $70 \%$ accuracy based on neural analysis of a US image of the CL and evaluation of its texture 18 days after insemination. At this stage, it is possible to decide on an appropriate oestrus RES programme. Special programmes may be pre-installed in US scanners for the evaluation of pertinent images and which support the diagnosis of early pregnancy (20). An alternative to ultrasound examination is the detection of pregnancy-specific glycoproteins (PAG) $(40,49)$. They appear in the blood (and milk) of pregnant cows relatively early after successful insemination. PAG, which gradually increase until approximately day 240 of pregnancy, reach a concentration of $>1 \mathrm{ng} / \mathrm{mL}$ in blood serum around day 28 , and can then be detected by particular tests (12, 13). A low concentration or lack of PAG corresponds to no pregnancy. For a short time, PAG have been determinable with so-called visual pregnancy tests 28 days post insemination (dpi) in blood (heifer and cow) or milk (cow). Our and others' observations indicate that such an examination can be carried out with high accuracy using whole blood, plasma, or serum as early as on day 25 (23) or even 24 post insemination (37). An advantage of the tests is their high specificity (24). Currently, they are an interesting alternative to a US scan in analogous periods - especially during mass examinations on large industrial cattle farms $(10,24)$. Early pregnancy diagnosis using progesterone tests or detection of early pregnancy factors (EPF) is at present of minor significance (15). Some hopes are also associated with defining the expression of certain genes and, possibly, with accurate validation of the echotexture and vascularisation of the $\mathrm{CL}$ around 18 dpi $(5,45)$. Recent research indicates that it is possible to outline a mathematical model which allows pregnancy to be detected at $21 \mathrm{dpi}$ based on the value of blood flow in corpora lutea, their size and echotexture of the uterus. The sensitivity and specificity of the method are 97\%. Despite good results, at present it is not used on a wider scale in field conditions. However, this does not rule out the possibility of its use in the near future (45).

Re-insemination after applying prostaglandin or using the OvSynch programme. The most frequently used tools for shortening the time to reinsemination of non-pregnant cows are the injection of prostaglandin, the OvSynch protocol, or modifications of it $(35,44)$. A frequent element accompanying the protocol is a detailed, ultrasound examination of the ovaries of non-pregnant cows and targeted hormonal therapy $(22,27,46)$.

Resynchronisation (Resynch) after determination of the functional status of ovaries - short vs. long Resynch programme. In our recent study (21), nonpregnant cows were divided into two groups: cows with a well-developed CL and those without a CL (NCL). Females from the first group were injected with cloprostenol (CLO) and inseminated according to the oestrus symptoms randomly after $80 \mathrm{~h}$ (CLO-80). In the second group, cows were inseminated depending on the size of the Graafian follicles at 16-23 h (PG-16) or 24-30 h (PG-24) after GnRH application. The highest pregnancy rate was obtained in the CLO-80 and PG-16 groups. The highest pregnancy rate among the cows without a CL was obtained as a result of progesterone intravaginal devices and injection of $500 \mu \mathrm{g}$ of cloprostenol and $105 \mu \mathrm{g}$ of buserelin $48 \mathrm{~h}$ later. The lowest pregnancy rate was observed in the protocol providing a single intramuscular application of buserelin.

In non-pregnant cows with a CL, oestrus induction is a widely practiced tool, often paired with TAI. Two groups of non-pregnant cows were subjected to a $32 \mathrm{~h}$ Resynch programme or a short Resynch programme (SR). Cows with a CL of more than $15 \mathrm{~mm}$ in diameter and with Graafian follicles of more than $10 \mathrm{~mm}$ in diameter received the first prostaglandin (PG) injection. A second PG application was given $24 \mathrm{~h}$ later and a GnRH injection $32 \mathrm{~h}$ thereafter. TAI was conducted 16 to $18 \mathrm{~h}$ after $\mathrm{GnRH}$ injection. The SR programme applied to pregnant cows with a CL shortened the time to the next pregnancy due to reduction of the period between inseminations, whereas in non-pregnant cows without a $\mathrm{CL}$ it resulted in a higher pregnancy rate per insemination (50).

Similar results were obtained when OvSynch (OVS) or Ultra-OVS programmes were used after the presence of a $\mathrm{CL}$ had been discovered $\left(\mathrm{PGF}_{2 \alpha}, 48 \mathrm{~h}\right.$ after $\mathrm{GnRH}$ injection and $24 \mathrm{~h}$ after insemination). The 
pregnancy rate on day 25 after TAI under the Ovsynch protocol was $28 \%$. (18). The study of Sani et al. (44) indicates that the calving rate in re-synchronised oestrus after using the OvSynch protocol did not differ from the calving rate after applying more complex programmes using oestradiol (1 mg intramuscularly) and progesterone (1.9 $\mathrm{g}$ with intravaginal device). The highest calving rates $(42.1 \%)$ were obtained after hormonal oestrus induction and insemination after $80 \mathrm{~h}$. The results may, however, be improved by introducing US examination (Ultra-OVS) for the purpose of more optimal selection of cows according to the size of the CL and accompanying follicle. On that basis, it is possible to implement an individual oestrus and ovulation induction programme, with timed artificial insemination. Epidemiologic data indicate that implementing Ultra-OVS, it is possible to obtain a calving rate of $51.5 \%$ (52). The results indicate the advantage of ovulation synchronisation based on preceding US diagnosis over an injection of hormones without prior gynaecological examination (so-called random application of hormones).

Nongravid animals which do not have a CL are injected with GnRH analogue or, in the case of suboestrus, the OvSynch programme is used. When comparing the use of prostaglandin injections for cows in which the CL was clinically or ultrasonographically defined as larger than $23 \mathrm{~mm}$ in diameter and random OvSynch on non-pregnant cows, no general differences were noted in the effectiveness of these hormonal programmes applied in dissimilar ways $(30,35)$. In the group of cows classified as non-pregnant at $32 \mathrm{dpi}$, lack of a CL was observed in $20 \%-30 \%$ of the cases. When subjected to RES, those cows had a 10\% lower calving rate than cows with an active CL. In comparison to the control group, a shortened time before the next insemination to $22-23$ days and a calving rate of $22 \%$ were obtained for three groups: cows which were injected with prostaglandin and inseminated according to external and internal heat symptoms, cows which demonstrated no heat symptoms, were administered prostaglandin, and inseminated $72-80 \mathrm{~h}$ later; and females which received prostaglandin and GnRH after another $48 \mathrm{~h}$ and inseminated according to heat symptoms (or, in the case of no heat symptoms, after GnRH application (48).

Protocols to improve results of calving for cows with diseases of the reproductive system have been recently reported by Giordiano et al. (17). Their findings indicate that a similar calving rate was achieved for Ovsynch + progesterone (P4) and PreGOvsynch programmes for cows without a CL, with a CL smaller than $15 \mathrm{~mm}$, or cows with luteal ovary cysts on the day of pregnancy detection and for cows with a CL larger $15 \mathrm{~mm}$ and subjected to a Resynch programme using $\mathrm{PGF}_{2 \alpha}$. It was found that cows from both groups needed similar time until the next calving.

The OvSynch programme for nongravid cows is used most frequently for oestrus RES regardless of the ovarian functional state. Its efficiency is determined by external factors as well as individual features. Programmes varied in efficiency and gave results which were not always satisfactory when implementations were investigated $(28,30,32,34,38$, 52). It was also described that factors which influence the effectiveness of OvSynch/TAI programmes are the location of pastures, type of diet, breed, body condition, post-partum period, climate, geographical location, and progesterone level on the day of the first $\mathrm{GnRH}$ analogue injection $(28,32,38,52)$. Recent data using OvSynch in cows (group 1) whose pregnancy was recorded ultrasonographically or palpatively on days 31 to 38 after insemination did not show any significant improvement of fertility, but in the group of previously examined cows (group 2), the rate of pregnancy diagnosed on day 61 after insemination was higher than in group 1 (34). After using the OvSynch protocol, McArt et al. (30) obtained similar calving rates as in the case of the UltraSynch programme, in which prostaglandin was injected only into those cows which had a CL of diameter more than $23 \mathrm{~mm}$. Cows were next inseminated according to clinical oestrus symptoms. If the diameter of the CL was smaller than $23 \mathrm{~mm}$, the OvSynch programme was used. However, the average times until calving in the UltraSynch and OvSynch groups were 98 and 87 days, respectively. According to these authors (30), the effectiveness of UltraSynch can be significantly enhanced by improving the oestrus detection rate.

In other studies, it was proven that in the case of NCL cows progesterone devices seemed to be a more effective therapy for anoestrus and non-pregnancy in cows than the Ovsynch protocol (22).

Double application of PG with a 24-h interval. Barletta et al. (2) compared the effectiveness of the OvSynch protocol, OvSynch with additional PG injection, and OvSynch with a double dose of PG (50 $\mathrm{mg}$ of dinoprost) in one injection. Treating infertility in these ways, females were inseminated $16 \mathrm{~h}$ after the second dose of GnRH. The authors showed that a double injection of PG increased the percentage of females with complete luteolysis from $88 \%$ to $94 \%$. Such an effect was not achieved when a double dose of PG was administered during one injection.

Resynch of non-pregnant cows with the use of progesterone and its derivatives. In a difference from dairy cows, the programmes more frequently used in beef cows are those which are a combination of classic OvSynch and, for example, additional progesterone support (such as CoSynch with controlled internal drug release (CIDR)) $(1,3,8,27,42)$. On the other hand, Wijma et al. (51) consider that the fertility of nonpregnant cows can be improved by combining GnRH injection with progesterone support. Broader research on the use of synchronisation based on the OvSynch protocol with progesterone support was conducted by Bilby et al. (4). They aimed to determine the influence of exogenous $\mathrm{P} 4$ on the pregnancy rate defined during 
insemination (TAI), initiated in two different periods after an unsuccessful insemination. After ruling out pregnancy at $32 \mathrm{dpi}$, the cows were subjected to RES with the use of one of the four protocols based on the OVS-56 programme: 1) RES 32 days after AI without P4 supplement (32 RES-CON); 2) RES 32 days after AI with progesterone supplement as CIDR applied at the moment of starting the programme (32 RESCIDR); 3) RES 39 days after AI without progesterone supplement (39 RES-CON), and 4) RES 39 days after AI with progesterone CIDR device applied at the beginning of the programme (39 RES-CIDR). Cows were inseminated earlier if oestrus occurred before the set date of insemination (4).

The pregnancy rate was determined 32 and 60 days after TAI. On the day of GnRH analogue and PG injections, cows were subjected to US examination of ovaries and blood samples were collected in order to measure the P4. The percentage of cows with a CL at the time of the first GnRH (G1) injection had no significant impact on the duration of treatment. However, the percentage of cows with a CL at the moment of PG injection was higher on day 32 RES subjects than in cows in which RES began on day 39 after insemination $(87.9 \%$ vs. $79.4 \%)$. The percentage of cows with a P4 level $\geq 1 \mathrm{ng} / \mathrm{mL}$ in blood during G1 had no impact on the duration of treatment, but it was higher at the moment of applying prostaglandin among the cows selected for RES starting on day $32(86.5 \%$ vs. $74.3 \%)$. The treatment had no influence on the pregnancy rate after TAI $(30.1 \%$ for 32 RESCON, $28.8 \%$ for 32 RES-CIDR, $27.5 \%$ for 39 RESCON, and $30.5 \%$ for 39 RES-CIDR).

In a further study (3), it was demonstrated that the use of a CIDR progesterone intravaginal device for 8 days increased the pregnancy rate, as the RES programme started on day 32 after an unsuccessful insemination (23.7\% for CON vs. $28.0 \%$ for CIDR). The applied treatment had no impact on miscarriages. A higher pregnancy rate on day 60 after TAI was noted when progesterone supplement (CIDR, for 8 days) was applied in cows without a CL at the first GnRH injection (28.2\% for CON-CL, $19.2 \%$ for CON-without CL, $27.0 \%$ for CIDR-CL, and $26.5 \%$ for CIDR-without $\mathrm{CL})$. In addition, cows without $\mathrm{CL}$ and progesterone levels lower than $1 \mathrm{ng} / \mathrm{mL}$ demonstrated the following pregnancy rates: $27.8 \%$ for CON-high $\mathrm{P} 4,15.0 \%$ for CON-low P4, 25.0\% for CIDR-high P4, and 29.4\% for CIDR-low P4.

The insertion of a CIDR device (1.38 g) for 8 days to replenish the $\mathrm{P} 4$ level increased the pregnancy rate of cows when RES was started on days 36-42 after insemination. That was not the case when RES was started on day 32. In a Polish study, it was confirmed that in absence of a CL, progesterone devices seem to be more effective in therapy of anoestrus and nonpregnancy than the Ovsynch protocol (22).

Bartolome et al. (3) published a complex programme of heat RES. It contained an effective timed artificial insemination based on PreSynch and OvSynch programmes combined with progesterone injections and re-insemination preceded by repeated supplementation with P4 (1.38 g) for 8 days (intravaginal device). According to the protocol, the cows received prostaglandin 38 and 24 days before the second insemination (i.e. on days 39 and 53 after the first insemination), GnRH on day $10, \mathrm{PG}$ on day 3 , and another GnRH analogue injection one day before insemination. Additionally, intravaginal CIDR devices were applied 10 and 3 days before insemination. Some cows received another CIDR device between days 14 and 23 after insemination (Resynch CIDR). The remaining females served as the control group (Resynch control). Cows of both groups received a GnRH injection on day 23. Cows in oestrus between days 0 and 30 were re-inseminated at detected oestrus (RIDE). US examination to confirm pregnancy was done 30 days after insemination. Non-pregnant cows received $\mathrm{PG}$ injections, and after GnRH application, they were inseminated at random (on day 33 after a previous unsuccessful insemination). The animals were tested for pregnancy 30 and 55 days after insemination. The results showed that the use of a CIDR device combined with PreSynch and OVS had no significant impact on the pregnancy rate of cows which were re-inseminated after being previously found non-pregnant. It was $36.1 \%$ and $33.5 \%$ on days 30 and 55, respectively. Cows from the control group without CIDR devices presented slightly lower pregnancy rates of $34.1 \%$ and $28.8 \%$, respectively. It was further found that CIDR application prior to insemination resulted in a decrease in pregnancy losses compared to cows without devices $(7.0 \%$ vs. $15.6 \%)$. On the other hand, application of CIDR devices between 14 and 23 days after the first insemination had no impact on the pregnancy rate on days 30 and 55 (24.7\% and $22.7 \%$, respectively) in comparison to cows who did not receive a CIDR device $(28.6 \%$ and $25.3 \%$, respectively). It is worth noting that these programmes did not include prior US examination of the ovaries.

In research conducted on Nelore cattle (bos indicus), two hormones were compared by being used separately to synchronise the follicle wave: oestradiol benzoate (EB) and gonadoliberin (a GnRH analogue). Additionally, norgestomet was implanted at the time of application of one of the hormones. Pregnancy was tested by ultrasonography seven days after removing the implant from the ear. Nongravid heifers received an injection of prostaglandin and $1 \mathrm{mg}$ of oestradiol cypionate $48 \mathrm{~h}$ after insemination. The pregnancy rates after the first TAI were similar for EB and GnRH at $41.9 \%$ and $41.5 \%$, respectively. However, heifers treated with EB had a higher calving rate after RES $(49.3 \%)$ than heifers injected with GnRH (37.2\%). It was stated that the application of $1 \mathrm{mg}$ EB on day 22 after the first TAI in heifers with unknown pregnancy status resulted in higher pregnancy rates in RES than the application of $\mathrm{GnRH}$ (43). 
Sponges containing $300 \mathrm{mg}$ of medroxyprogesterone (MAP) were also used in cows to re-synchronise oestrus. They were introduced into the vagina 13 days after TAI and removed at $20 \mathrm{dpi}$. At the same time, $1 \mathrm{mg}$ of oestradiol benzoate was applied. This method of RES allowed the period between TAI and the next insemination to be shortened to 37 days. The rate of pregnancy in cows after pursuing the programme was, however, barely better than half that of females which were not subjected to the programme (6).

Oestrus resynchronisation. Various detectors are used in order to improve oestrus detection and insemination results. They are mainly based on registering increased activity proportional to cows' sexual cycles and include pedometers, accelerometers, and activity meters $(26,31)$. Combining oestrus RES and electronic oestrus detection may be an important element in shortening the period until the next insemination. One of the first experiments undertaken in this field compared the fertility of cows subjected to a hormonal programme during the second and subsequent inseminations (16). The goal of that experiment was to improve the fertility of cows due to monitoring of their physical activity and insemination as dictated thereby (AIAct) and pre-synchronisation of females which did not show predictive activity and their TAI by means of the Ovsynch programme (non AIAct). Cows from the control group (CON) were subjected to the programme, which combined AIAct and TAI after prior use of the Ovsynch programme. Excluding pregnancy by means of US examination at $31 \mathrm{dpi}$, cows were assigned to control and treatment groups and subjected to RES according to the following patterns. In the event of no pregnancy, the control group (CON-AIAct) was resynchronised according to the Ovsynch-56 protocol ( $\mathrm{GnRH}, \mathrm{PG} 7$ days later, GnRH56 $\mathrm{h}$ thereafter, insemination after $16 \mathrm{~h}$ ). In the treatment groups (TRT), females with a $C L \geq 20 \mathrm{~mm}$ (TRT-CL) received an injection of $\mathrm{PG}$ one day after ruling out pregnancy, whereas cows without a $\mathrm{CL}$ or with a $\mathrm{CL} \leq 20 \mathrm{~mm}$ (TRT-NoCL) received $\mathrm{GnRH}$ on day 3. In physically inactive cows from the TRT-CL and TRT-NoCL groups, an Ovsynch+CIDR programme was used (GnRH/- CIDR device for 8 days, application of PG 5 days after removal of progesterone device; PG injection $24 \mathrm{~h}$ later; GnRH after $32 \mathrm{~h}$, and insemination $16 \mathrm{~h}$ thereafter) 9 and 7 days after $\mathrm{PGF}_{2} \alpha$ or GnRH injection, respectively.

The probability of pregnancy until the $270^{\text {th }}$ day in milk (DIM) was similar between cows from the CON and TRT groups, but it was dependent on their number of lactations and was higher in primi- than in multiparous cows. Neither were differences noted in the average number of days to calving when comparing the control and treatment groups. The estimated chance for pregnancy until the $104^{\text {th }}$ DIM was similar between control and treated cows. Pregnancy was most frequently noted at $161 \mathrm{dpi}$ in the CON group and at $178 \mathrm{dpi}$ in the TRT group. Despite a higher percentage of cows demonstrating increased physical activity in the experimental (treated) group (AIAct) $(29 \%$ and $10 \%$ for TRT and CON, respectively), the average number of days after insemination until pregnancy was detected in this group was higher (by 17 days) than in the control group (10 days). Thus, no significant influence of combining electronic heat detection and hormonal programmes was detected in relation to cows' general fertility (14).

Table 1 presents selected RES programmes and their effectiveness.

Hormonal programmes in relation to new methods of early pregnancy diagnosis. In cows subjected to oestrus and ovulation synchronisation in combination with TAI, diagnosis of pregnancy is mostly undertaken 32 dpi. Non-pregnant cows, regardless of their ovarian function, are subjected to an added RES (39). In such cases, the Ovsynch protocol is initiated on days 25 or 26 after TAI (ReSynch-19, ReSynch-21, ReSynch-25, or ReSynch-26), which allows the number of days until calving to be reduced and the pregnancy rate among dairy cows to be increased $(33,51)$. Earlier initiation of oestrus RES is possible due to newer methods of early pregnancy diagnosis (ultrasonography and visual pregnancy test). However opinions vary regarding the use of tools for early pregnancy diagnosis in combination with TAI programmes. Although injecting pregnant cows with GnRH 19 days after the first TAI did not result in iatrogenic embryo loss, it did lower the calving rate in comparison to the rate obtained with the initiation of the Resynch programme 26 or 33 days after the first TAI (11). Similarly, RES with the use of GnRH injected on day 21 after AI, for the purpose of initiating a TAI protocol before pregnancy diagnosis (day 28 after AI), did not influence the pregnancy rate or pregnancy loss rate in dairy cows (7). According to Silva et al. (46), an early RES after PAG-ELISA did not have any impact on the calving rate after TAI, but it reduced the number of days between ruling out pregnancy and calving. In relation to TAI, early pregnancy tests may increase the number of calved cows in comparison with a transrectal US examination at a later time point after insemination. RES of cows using the OvSynch programme in the case of early (PAG ELISA, 27-34 days after insemination in an early resynchronisation (ER) group) or late pregnancy diagnosis (palpative pregnancy diagnosis, 35-52 days after insemination in a late resynchronisation (LR) group) had no impact on the inter-pregnancy period, although the percentage of non-pregnant and reinseminated cows was higher in the ER group than in the LR group (47). 
Table 1. Resynchronisation programmes for heat and their effectiveness

\begin{tabular}{|c|c|c|c|c|c|c|c|}
\hline $\begin{array}{l}\text { Day and } \\
\text { method of early } \\
\text { pregnancy } \\
\text { examination } \\
\text { (after TAI) }\end{array}$ & $\begin{array}{l}\text { Programme and } \\
\text { day after TAI }\end{array}$ & $\begin{array}{l}\text { Day after AI } \\
\text { and method of } \\
\text { traditional } \\
\text { pregnancy } \\
\text { examination }\end{array}$ & $\begin{array}{l}\text { Method of } \\
\text { ovary } \\
\text { examination in } \\
\text { non-pregnant } \\
\text { cows and } \\
\text { criteria for the } \\
\text { diagnosis of } \\
\text { functional } \\
\text { structures on } \\
\text { the ovaries }\end{array}$ & $\begin{array}{l}\text { Hormonal } \\
\text { programme } \\
\text { after } \\
\text { pregnancy } \\
\text { examination }\end{array}$ & $\begin{array}{l}\text { Pregnancy } \\
\text { rate }(\%)\end{array}$ & Comments & References \\
\hline $\begin{array}{l}18 \text { d expression } \\
\text { of Oas } 1 \\
\text { and plasma } \\
\text { progesterone } \\
\text { concentration }\end{array}$ & Resynch-21 & $\begin{array}{l}27 \mathrm{~d} \text { after TAI } \\
-\mathrm{TU}\end{array}$ & $\begin{array}{l}\text { No functional } \\
\text { evaluation of } \\
\text { ovarian status }\end{array}$ & $\begin{array}{l}\text { PG } 19 \text { d + } \\
\text { GnRH } 12 \text { d } \\
\text { after TAI }\end{array}$ & $\begin{array}{l}50 \\
51.7\end{array}$ & & $\begin{array}{l}\text { Green et } \\
\text { al. (19) }\end{array}$ \\
\hline $\begin{array}{l}13 \text { and } 20 \mathrm{~d} \\
\text { progesterone } \\
\text { concentration in } \\
\text { milk }\end{array}$ & $\begin{array}{l}13 \text { d EB+MAP } \\
13-20 \text { d after } \\
\text { TAI } \\
\text { Control - no } \\
\text { MAP }\end{array}$ & $\begin{array}{l}45 \mathrm{~d} \text { after TAI } \\
\text { - palpation per } \\
\text { rectum }\end{array}$ & $\begin{array}{l}\text { No functional } \\
\text { evaluation of } \\
\text { ovarian status }\end{array}$ & & $\begin{array}{l}22.8 \\
47.4\end{array}$ & $\begin{array}{l}\text { EB+MAP } \\
\text { Significant } \\
\text { reduction of the } \\
\text { period from TAI to } \\
\text { RES }\end{array}$ & $\begin{array}{l}\text { Cavestany } \\
\text { et al. }(6)\end{array}$ \\
\hline - & $\begin{array}{l}\text { Resynch-19 } \\
\text { Resynch-26 } \\
\text { Resynch-33 }\end{array}$ & $\begin{array}{l}28 \mathrm{~d} \text { after } \\
\text { TAI-TU and } \\
68 \mathrm{~d} \text { after TAI } \\
\text { - palpation } \\
\text { per rectum }\end{array}$ & $\begin{array}{l}\text { No functional } \\
\text { evaluation of } \\
\text { ovarian status }\end{array}$ & - & $\begin{array}{l}23 \\
34 \\
38\end{array}$ & & $\begin{array}{l}\text { Fricke } \text { et } \\
\text { al. (11) }\end{array}$ \\
\hline \multirow[t]{6}{*}{$\begin{array}{l}21 \text { d plasma } \\
\text { progesterone } \\
\text { concentration }\end{array}$} & $\begin{array}{l}\text { Resynch-21 } \\
\text { Control }\end{array}$ & $\begin{array}{l}26 \mathrm{~d} \text { after TAI- } \\
\text { TU } \\
35 \mathrm{~d} \text { after TAI } \\
\text { - palpation per } \\
\text { rectum }\end{array}$ & $\begin{array}{l}\text { No functional } \\
\text { evaluation of } \\
\text { ovarian status }\end{array}$ & & $\begin{array}{l}33.1 \\
33.6\end{array}$ & $\begin{array}{l}\text { no significant } \\
\text { differences in the } \\
\text { extent of pregnancy } \\
\text { losses between } 21 \\
\text { and } 28 \text { d after TAI }\end{array}$ & $\begin{array}{l}\text { Chebel et } \\
\text { al. (7) }\end{array}$ \\
\hline & $\begin{array}{l}22 \mathrm{dEB}+\mathrm{NOR} \\
22 \mathrm{~d} \mathrm{GnRH}+ \\
\text { NOR }\end{array}$ & $\begin{array}{l}30 \mathrm{~d} \text { after TAI- } \\
\text { TU }\end{array}$ & $\begin{array}{l}\text { No functional } \\
\text { evaluation of } \\
\text { ovarian status }\end{array}$ & & $\begin{array}{l}49.3 \\
37.2\end{array}$ & & $\begin{array}{l}\text { Sa Filho et } \\
\text { al. (43) }\end{array}$ \\
\hline & $\begin{array}{l}\text { Short Resynch } \\
\text { (immediately } \\
\text { after NPD) }\end{array}$ & $\begin{array}{l}32 \mathrm{~d} \text { after TAI- } \\
\text { TU }\end{array}$ & $\begin{array}{l}\text { TU } \\
\text { CL }>15 \\
\text { follicle }>10 \\
\text { mm }\end{array}$ & & 32.7 & $\begin{array}{l}\text { Average time for } \\
\text { effective } \\
\text { insemination }-95 \mathrm{~d} \\
\text { Average time for } \\
\text { effective } \\
\text { insemination } \\
-70 \mathrm{~d}\end{array}$ & $\begin{array}{l}\text { Wijma et } \\
\text { al. }(50)\end{array}$ \\
\hline & $\begin{array}{l}\text { OvSynch } 31 \mathrm{~d} \\
\text { after TAI } \\
\text { OvSynch } 31 \mathrm{~d} \\
\text { after TAI }\end{array}$ & $\begin{array}{l}31 \mathrm{~d} \text { after TAI- } \\
\text { TU } \\
38 \mathrm{~d} \text { after TAI } \\
\text { - palpation per } \\
\text { rectum }\end{array}$ & $\begin{array}{l}\text { No functional } \\
\text { evaluation of } \\
\text { ovarian status }\end{array}$ & & 26.4 & $\begin{array}{l}\text { Minimum } \\
\text { economic } \\
\text { differences depend } \\
\text { on the date of } \\
\text { pregnancy } \\
\text { examination } \\
\text { No significant } \\
\text { differences in the } \\
\text { reproduction of } \\
\text { cows }\end{array}$ & $\begin{array}{l}\text { Pereira et } \\
\text { al. (34) }\end{array}$ \\
\hline & $\begin{array}{l}\text { 14-23 d CIDR } \\
+ \text { OvSynch } 23 \\
\text { d } \\
\text { Control group } \\
\text { without CIDR }\end{array}$ & $\begin{array}{l}30 \mathrm{~d} \\
\text { after TAI-TU }\end{array}$ & $\begin{array}{l}\text { No functional } \\
\text { evaluation of } \\
\text { ovarian status }\end{array}$ & $\begin{array}{l}\text { PG } 30 d \\
\text { PG } 30 d\end{array}$ & $\begin{array}{l}24.7 \\
28.6\end{array}$ & $\begin{array}{l}7 \% \text { pregnancy } \\
\text { losses } \\
15.6 \% \text { pregnancy } \\
\text { losses }\end{array}$ & $\begin{array}{l}\text { Bartolome } \\
\text { et al. (3) }\end{array}$ \\
\hline & $\begin{array}{l}\text { N-CIDR } \\
\text { U-CIDR } \\
\text { OvSynch }\end{array}$ & $\begin{array}{l}28 \mathrm{~d} \text { after TAI- } \\
\text { TU }\end{array}$ & $\begin{array}{l}\text { No functional } \\
\text { evaluation of } \\
\text { ovarian status }\end{array}$ & & $\begin{array}{l}35.9 \\
29.6 \\
21.2\end{array}$ & & $\begin{array}{l}\text { El- } \\
\text { Tarabany } \\
(9)\end{array}$ \\
\hline
\end{tabular}

TU - transrectal ultrasonography; CL - corpus luteum; CIDR - controlled internal drug release; TAI - timed artificial insemination; EB - oestradiol benzoate; MAP - medroxyprogesterone acetate; NOR - norgestomet; NPD - nonpregnancy diagnosis; N-CIDR - new CIDRsynch; U-CIDR - reused CIDRsynch 
On the other hand, using pre-synchronisation of the oestrus cycle in dairy cows administered GnRH by injection seven days before initiating the RES protocol or given a CIDR device in the RES protocol resulted in a higher pregnancy rate after another AI RES than that in the cows from the control group (8). An original method of shortening to 21 days the period between the first TAI, the ruling out of pregnancy and subsequent insemination is proposed by a method based on early detection of pregnancy along with use of appropriate hormonal intervention (19). It involves estimating (using pre-defined border values) the mRNA expression level of 2'-5' oligoadenylate synthase 1 gene (Oas1) in leukocytes, and the concentration of progesterone in blood plasma on day 18 after TAI (day 0). It was found that heifers which did not conceive after the first TAI had a higher Oas1 mRNA abundance on the day of PG injection (3 days before TAI) than pregnant heifers. On day 18 after TAI, however, it was observed that pregnant heifers had a fivefold higher mRNA abundance of the Oas1gene in comparison with non-pregnant females. Further measures on non-pregnant heifers involved an application of prostaglandin on day $19, \mathrm{GnRH}$ two days later, and TAI.

The abovementioned research is of a preliminary nature, although it already indicates the existence of new possibilities in the field of early pregnancy diagnostics in combination with simple targeted hormonal intervention. They may reduce the use of hormones in fertility management programmes or contribute to the reduction in the number of open days.

Conflict of Interests Statement: The authors declare that there is no conflict of interests regarding the publication of this article.

Financial Disclosure Statement: The present study was self-funded.

Animal Rights Statement: None required.

\section{References}

1. Arshad U., Qayyum A., Hassan M., Husnain A., Sattar A., Ahmad N.: Effect of resynchronization with GnRH or progesterone (P4) intravaginal device (CIDR) on day 23 after timed artificial insemination on cumulative pregnancy and embryonic losses in CIDR-GnRH synchronized Nili-Ravi buffaloes. Theriogenology. 2017, 103, 104-109.

2. Barletta R.V., Carvalho P.D., Santos V.G., Melo L.F., Consentini C.E., Netto A.S., Fricke P.M.: Effect of dose and timing of prostaglandin F2 $\alpha$ treatments during a Resynch protocol on luteal regression and fertility to timed artificial insemination in lactating Holstein cows. J Dairy Sci 2018, 101, 1730-1736.

3. Bartolome J.A., van Leeuwen J.J., Thieme M., Sa Filho O.G., Melendez P., Archbald L.F., Thatcher W.W.: Synchronization and resynchronization of inseminations in lactating dairy cows with the CIDR insert and the Ovsynch protocol. Theriogenology 2009, 72, 869-878.
4. Bilby T.R., Bruno R.G., Lager K.J., Chebel R.C., Moraes J.G., Fricke P.M., Lopes G. Jr., Giordano J.O., Santos J.E., Lima F.S., Stevenson J.S., Pulley S.L.: Supplemental progesterone and timing of resynchronization on pregnancy outcomes in lactating dairy cows. J Dairy Sci 2013, 96, 7032-7042.

5. Carvalho P.D., Consentini C.C., Weaver S.R., Barleta R.V., Hernandez L.L., Fricke P.M.: Temporarily decreasing progesterone after timed artificial insemination decreased expression of interferon-tau stimulated gene 15 (ISG15) in blood leukocytes, serum pregnancy-specific protein B concentrations, and embryo size in lactating Holstein cows. J Dairy Sci 2017, 100, 3233-3242.

6. Cavestany D., Cibils J., Freire A., Sastre A., Stevenson J.S.: Evaluation of two different oestrus-synchronisation methods with timed artificial insemination and resynchronisation of returns to oestrus in lactating Holstein cows. Anim Reprod Sci 2003, 77, 141-155.

7. Chebel R.C., Santos J.E.P., Cerri L.R.A., Galvão K.N., Juchem S.A., Thather W.W.: Effect of resynchronization with $\mathrm{GnRH}$ on day 21 after artificial insemination on pregnancy rate and pregnancy loss in lactating dairy cows. Theriogenology, 2003, 60, 1389-1399.

8. Dewey S.T., Mendonça L.G., Lopes G. Jr., Rivera F.A., Guagnini F., Chebel R.C., Bilby T.R.: Resynchronization strategies to improve fertility in lactating dairy cows utilizing a presynchronization injection of $\mathrm{GnRH}$ or supplemental progesterone. I. Pregnancy rates and ovarian responses. J Dairy Sci 2010, 93, 4086-4095. doi: 10.3168/jds.2010-3233.

9. El-Tarabany M.S.: The efficiency of new CIDR and once-used CIDR to synchronize ovulation in primiparous and multiparous Holstein cows. Anim Reprod Sci 2016, 173, 29-34. doi: 10.1016/j.anireprosci.2016.08.006.

10. Fosgate G.T., Motimele B., Ganswindt A., Irons P.C.: A Bayesian latent class model to estimate the accuracy of pregnancy diagnosis by transrectal ultrasonography and laboratory detection of pregnancy-associated glycoproteins in dairy cows. Prev Vet Med 2017, 15, 100-109.

11. Fricke P.M., Caraviello D.Z., Weigel K.A., Welle M.L.: Fertility of dairy cows after resynchronization of ovulation at three intervals following first timed insemination. J Dairy Sci 2003, 86, 3941-3950.

12. Fricke P.M., Ricci A., Carvalho P.D., Mason C., Amundson M.C.: milk vs. blood - which is best for PAG pregnancy prediction? Western Dairy Management Conference, Reno 2015.

13. Gajewski Z., Melo de Sousa N., Konopka A.: Determination of PAG in the milk and blood in cow's in comparison to other examination methods for pregnancy diagnosis. Procedings XXV WBC, Budapest 2008, pp. 92-97.

14. Galvão K.N., Santos J.E.: Factors affecting synchronization and conception rate after the Ovsynch protocol in lactating Holstein cows. Reprod Domest Anim 2010, 45, 439-446.

15. Giordano J.O., Fricke P.M., Cabrera V.E.: Economics of resynchronization strategies including chemical tests to identify non-pregnant cows. J. Dairy Sci 2013, 96, 949-961.

16. Giordano J.O., Stangaferro M.L., Wijma R., Chandler W.C., Watters R.D.: Reproductive performance of dairy cows managed with a program aimed at increasing insemination of cows in estrus based on increased physical activity and fertility of timed artificial inseminations. J Dairy Sci 2015, 98, 2488-2501.

17. Giordano J.O., Thomas M.J., Catucuamba G., Curler M.D., Masello M., Stangaferro M.L., Wijma R.: Reproductive management strategies to improve the fertility of cows with a suboptimal response to resynchronization of ovulation. J Dairy Sci 2016, 99, 2967-2978.

18. Giordano J.O., Wiltbank M.C., Guenther N.J., Pawlish R., Bas S., Cunha A.P., Fricke P.M.: Increased fertility in lactating dairy cows resynchronized with Double-Ovsynch compared with Ovsynch initiated $32 \mathrm{~d}$ after timed artificial insemination. Resynchronization with double-ovsynch. J. Dairy Sci 2012, 95, 639-653. 
19. Green J.C., Okamura C.S., Mathew D.J., Newsom E.M., Lucy M.C.: Hot topic: successful fixed-time insemination within $21 \mathrm{~d}$ after first insemination by combining chemical pregnancy diagnosis on d 18 with a rapid resynchronization program. J Dairy Sci 2010, 93, 5668-5672.

20. Górna K., Zaborowicz M., Jaśkowski B.M., Jaśkowski J.M., Boniecki P., Okoń P., Kozłowski R.J., Przybył J.: Neural analysis of bovine ovaries ultrasound images in the identification process of the corpus luteum - preliminary study. Ninth International Conference on Digital Image Processing (ICDIP 2017), Hong Kong, China, 2017, 104204h-6.

21. Herudzińska M., Nalaskowska M., Jaśkowski B.M., Gehrke M., Kulus J., Jaśkowski J.M.: Conception rate after different models of treatment in non-pregnant cows, $30^{\text {th }}$ World Buiatric Congress, Sapporo, 2018 (in press).

22. Herudzińska M., Nalaskowska M., Jaśkowski B.M., Niewitecki W., Kulus J., Jaśkowski J.M.: Progesterone devices and Ovsynch - efficacy in anestrus and non-pregnant dairy cows - retrospective study. $30^{\text {th }}$ World Buiatric Congress, Sapporo, 2018 (in press).

23. Jaśkowski J.M., Herudzińska M., Kmiecik J., Jaśkowski B.M., Kierbić A., Kulus J.: Wstępne uwagi dotyczące wykorzystania testu terenowego do wykrywania wczesnej ciąży u krów. Lecznica Dużych Zwierząt 2017, 11, 55-59.

24. Jaśkowski J.M., Herudzińska M., Kmiecik J., Kierbić A., Jaśkowski B.M., Gehrke M.: New possibilities for pregnancy diagnosis in ruminants: limitations, advantages, use. Med Weter 2018, 74, 349-355.

25. Jaśkowski J.M., Kaczmarowski M., Kulus J., Jaśkowski B.M., Herudzińska M., Gehrke M.: Palpation per rectum on pregnancy in cows - a past or an alternative to modern diagnostic methods. Med Weter 2018 (in press).

26. Jaśkowski J.M., Kmiecik J., Kierbić A., Herudzińska M., Woźna-Wysocka M.: Automatic cow heat detection systems as a tool to improve herd management. Med Weter 2018, 74, 434-440.

27. Kelley D.E., Ibarbia L., Daetz R., Bittar J.H., Risco C.A., Santos J.E., Ribeiro E.S., Galvão K.N.: Combined use of progesterone inserts, ultrasonography, and GnRH to identify and resynchronize non-pregnant cows and heifers 21 days after timed artificial insemination. Theriogenology 2016, 85, 230-237.

28. Lamb G.C., Dahlen C.R., Larson J.E., Marquezini G., Stevenson J.S.: Control of the estrous cycle to improve fertility for fixed-time artificial insemination in beef cattle: a review. J Anim Sci 2010, 88, 181-192. doi: 10.2527/jas.2009-2349.

29. Macmillan K.L.: Recent advances in the synchronization of estrus and ovulation in dairy cows. J Reprod Dev 2010, 56, 42-47.

30. McArt J.A., Caixeta L.S., Machado V.S., Guard C.L., Galvao K.N., Sá Filho O.G., Bicalho R.C.: Ovsynch versus Ultrasynch: reproductive efficacy of a dairy cattle synchronization protocol incorporating corpus luteum function. J Dairy Sci 2010, 93, 2525-2532.

31. Michaelis I., Burfeind O., Heuwieser W.: Evaluation of oestrous detection in dairy cattle comparing an automated activity monitoring system to visual observation. Reprod Domest Anim 2014, 49, 621-628.

32. Motavalli T., Dirandeh E., Deldar H., Colazo M.G.: Evaluation of shortened timed-AI protocols for resynchronization of ovulation in multiparous Holstein dairy cows. Theriogenology 2017, 95, 187-192.

33. Osawa T., Honju S., Nitta H., Uchiza M., Tameoka N., Moro Y., Izaike Y.: Effect of synchronization of ovulation on ovarian profile and days open in holstein cows diagnosed as nonpregnant 26 days after timed artificial insemination. J Reprod Dev 2009, 55, 163-169.

34. Pereira R.V., Caixeta L.S., Giordano J.O., Guard C.L., Bicalho R.C.: Reproductive performance of dairy cows resynchronized after pregnancy diagnosis at $31( \pm 3)$ days after artificial insemination (AI) compared with resynchronization at
$31( \pm 3)$ days after AI with pregnancy diagnosis at $38( \pm 3)$ days after AI. J Dairy Sci 2013, 96, 7630-7639.

35. Rabiee A.R., Lean I.J., Stevenson M.A.: Efficacy of Ovsynch program on reproductive performance in dairy cattle: a metaanalysis. J Dairy Sci 2005, 88, 2754-2770.

36. Racewicz P., Sickinger M., Włodarek J., Jaśkowski J.M.: Ultrasonographic diagnosis of early pregnancy in cattle using different ultrasound systems. Tierarztl Prax Ausg G Grosstiere Nutztiere 2016, 44, 151-156.

37. Reese S.T., Pereira M.H.C., Edwards J.L., Vasconcelos J.L.M., Pohler K.G.: Pregnancy diagnosis in cattle using pregnancy associated glycoprotein concentration in circulation at day 24 of gestation. Theriogenology 2018, 106, 178-185. doi: 10.1016/j.theriogenology.2017.10.020.

38. Ribeiro E.S., Cerri R.L., Bisinotto R.S., Lima F.S., Silvestre F.T., Greco L.F., Thatcher W.W., Santos J.E.: Reproductive performance of grazing dairy cows following presynchronization and resynchronization protocols. J Dairy Sci 2011, 94, 4984-4996.

39. Ricci A., Carvalho P.D., Amundson M.C., Fricke P.M.: Characterization of luteal dynamics in lactating Holstein cows for 32 days after synchronization of ovulation and timed artificial insemination. J Dairy Sci 2017, 100, 9851-9860.

40. Ricci A., Carvalho P.D., Amundson M.C., Fourdraine R.H., Vincenti L., Fricke P.M.: Factors associated with pregnancyassociated glycoprotein (PAG) levels in plasma and milk of Holstein cows during early pregnancy and their effect on the accuracy of pregnancy diagnosis. J Dairy Sci 2015, 98, 2502-2514.

41. Romano J.E., Pinedo P., Bryan K., Ramos R.S., Solano K.G., Merchan D., Velez J.: Comparison between allantochorion membrane and amniotic sac detection by per rectal palpation for pregnancy diagnosis on pregnancy loss, calving rates, and abnormalities in newborn calves. Theriogenology 2017, 90, 219-227.

42. Rudolph J., Bruckmaier R.M., Kasimanickam R., Steiner A., Kirchhofer M., Hüsler J., Hirsbrunner G.: Comparison of the effect of a CIDR-Select Synch versus a long-term CIDR based AI protocol on reproductive performance in multiparous dairy cows in Swiss dairy farms. Reprod Biol Endocrinol 2011, 9, 151. doi: 10.1186/1477-7827-9-151.

43. Sá Filho M.F., Marques M.O., Girotto R., Santos F.A., Sala R.V., Barbuio J.P., Baruselli P.S.: Resynchronization with unknown pregnancy status using progestin-based timed artificial insemination protocol in beef cattle. Theriogenology 2014, 81, 284-290.

44. Sani R.N., Farzaneh N., Moezifar M., Seifi H.A., Tabatabei A.A.: Evaluation of five resynchronization methods using different combinations of PGF $2 \alpha, \mathrm{GnRH}$, estradiol, and an intravaginal progesterone device for insemination in Holstein cows. Anim Reprod Sci 2011, 124, 1-6.

45. Scully S., Butler S.T., Kelly A.K., Evans A.C., Lonergan P., Crowe M.A.: Early pregnancy diagnosis on days 18 to 21 post insemination using high-resolution imaging in lactating dairy cows. J Dairy Sci 2014, 97, 3542-3557.

46. Silva E., Sterry R.A., Kolb D., Mathialagan N., McGrath M.F., Ballam J.M., Fricke P.M.: Effect of interval to resynchronization of ovulation on fertility of lactating Holstein cows when using transrectal ultrasonography or a pregnancy-associated glycoprotein enzyme-linked immunosorbent assay to diagnose pregnancy status. J Dairy Sci 2009, 92, 3643-3650. doi: 10.3168/jds.2008-1704.

47. Sinedino L.D., Lima F.S., Bisinotto R.S., Cerri R.L., Santos J.E.: Effect of early or late resynchronization based on different methods of pregnancy diagnosis on reproductive performance of dairy cows. J Dairy Sci 2014, 97, 4932-4941. doi: 10.3168/jds.2013-7887.

48. Stevenson J.F., Cartmill J.A., Hensley B.A., El-Zarkouny S.Z., Metrics P.X.: Conception rates of dairy cows following early not-pregnant diagnosis by ultrasonography and subsequent 
treatments with shortened Ovsynch protocol Theriogenology 2003, 60, 475-483.

49. Szenci O., Beckers J.F., Humblot P., Sulon J., Sasser G., Taverne M.A.M., Varga J., Baltusen R., Schekk G.: Comparison of ultrasonography, bovine pregnancy-specific protein $\mathrm{B}$, and bovine pregnancy-associated glycoprotein 1 tests for pregnancy detection in dairy cows. Theriogenology 1998, 50, 77-88.

50. Wijma R., Pérez M.M., Masello M., Stangaferro M.L., Giordano J.O.: A resynchronization of ovulation program based on ovarian structures present at nonpregnancy diagnosis reduced time to pregnancy in lactating dairy cows. J Dairy Sci 2018, 101, $1697-1707$.
51. Wijma R., Stangaferro M.L., Masello M., Granados G.E., Giordano J.O.: Resynchronization of ovulation protocols for dairy cows including or not including gonadotropin-releasing hormone to induce a new follicular wave: effects on reinsemination pattern, ovarian responses, and pregnancy outcomes. J Dairy Sci 2017, 100, 7613-7625. doi: 10.3168/jds.2017-12550.

52. Yamada K.: JSAR Innovative Technology Award. Development of ovulation synchronization and fixed time artificial insemination in dairy cows. J Reprod Dev 2005, 51, 177-186. 